\title{
Matkanjärjestäjien lakisääteinen vastuu ihmisten sekä inmisten ja eläinten välillä tarttuvien tautien leviämisen ehkäisystä
}

Heli I. Koskinen, Helsingin yliopisto

Kevättalvella 2020 alkanut ja maailmanlaajuiseksi pandemiaksi yltynyt koronavirusepidemia on karulla tavalla osoittanut, että ihmisten lisäksi myös taudit liikkuvat maasta toiseen. Suomessa ei esiinny eikä ole esiintynyt moniakaan pelättyjä tappavia eläinten ja ihmisten välillä tarttuvia tauteja (Ruokavirasto, 2019), eikä niiden tulevaisuudessakaan haluta leviävän Suomeen esimerkiksi ulkomailta palaavien suomalaisten mukana. Suomalaiset voivat matkoilta palatessaan esimerkiksi olla monelle eri antibiootille vastustuskykyisten bakteerien kantajia. Kotimaahan palaajat saattavat myös tuoda mukanaan eläviä eläimiä tai eläimistä peräisin olevia elintarvikkeita, joissa elävät taudinaiheuttajat voivat sairastuttaa sekä ihmisiä että eläimiä. Esimerkiksi ulkomailta peräisin olevat sianlihatuotteet voivat levittää Suomeen afrikkalaista sikaruttoa (Pekkanen \& Laine, 2011/2017), ja laittomasti maahan tuodut eläimet, lähinnä koirat, ovat raivotautiriskin vuoksi uhka ihmisten terveydelle (Ribadeau-Dumaz ym., 2016).

Suomalaisessa eläintautilaissa (441/2013) säädetään 58 \$:n mukaan, että Suomesta toiseen jäsenvaltioon tai toisen jäsenvaltion kautta muuhun kuin jäsenvaltioon taikka toisesta jäsenvaltiosta Suomeen tai Suomen kautta kolmanteen jäsenvaltioon tai muuhun kuin jäsenvaltioon saa toimittaa vain sellaisia eläimiä ja eläimistä saatuja tuotteita, jotka täyttävät Euroopan unionin lainsäädännössä asetetut eläintautien vastustamista koskevat vaatimukset. Myöhemmin, vuonna 2019, lakiin on lisätty lailla eläintautilain muuttamisesta (349/2019) pykälä 59a, jonka mukaan "jäsenvaltioiden välisen matkustajaliikenteen harjoittajan, tällaiseen liikenteeseen käytettävän sataman tai lentoaseman pitäjän ja ulkomaanmatkoja myyvän matkanjärjestäjän tulee riittävällä ja toiminnan luonteeseen nähden tarkoituksenmukaisella tavalla jakaa matkustajille tietoa eläinten sekä niistä saatujen tuotteiden maan rajat ylittäviä siirtoja koskevista kielloista ja muista suojatoimenpiteistä, jotka johtuvat Suomessa tai toisessa jäsenvaltiossa todetusta helposti leviävän, vaarallisen tai uuden vakavan eläintaudin taudinpurkauksesta". Vastuuta on siis muiden mainittujen ohella myös ulkomaan matkoja myyvillä matkanjärjestäjillä. 
Lain 59a pykälän mukaan matkanjärjestäjillä on tiedonjakovelvollisuus, josta säädetään tarkemmin valtioneuvoston asetuksella 1339/2019. Asetuksessa ilmoitusvelvollisuus rajataan kuitenkin koskemaan vain afrikkalaista sikaruttoa ja sataman tai lentoaseman pitäjiä. Kesällä 2019 afrikkalaisen sikaruton levittyä jo Viroon, Latviaan, Liettuaan, Puolaan ja moneen muuhunkin Euroopan maahan Ruokavirasto esitti toiveenaan, että matkanjärjestäjät muistuttaisivat asiakkaitaan elintarvikkeiden tuonnin rajoituksista. Tätä varten on olemassa matkailijoille suunnattu internet-sivu, videoita ja painettuja tiedotteita. Tietoa on saatavilla suomeksi, ruotsiksi ja englanniksi sekä esitteitä myös viroksi ja venäjäksi. Aluehallintoviraston tiedotteissa (2016) muistutetaan, että suomalaiset eläinlääkintäviranomaiset jalkautuvat pistokoeluontoisesti rajanylityspaikoille, lähinnä satamiin, paitsi tekemään yleisiä lakisääteisiä tuontitarkastuksia myös neuvomaan yksityisiä kansalaisia ja jakamaan tietoa oikeista toimintatavoista.

Vaikka viranomainen suosittaa jakamaan tietoa tuontirajoituksista, pikainen katsaus kymmenen ensimmäisen google-haulla löytyvän matkanjärjestäjän internetsivuille huhtikuussa 2020 osoittaa, että asiaan liittyvää tiedotusta ei juurikaan löydy. Hakusanalla "afrikkalainen sikarutto" ei löydy yhtään osumaa. Edes Venäjän-matkoihin erikoistuneen matkanjärjestäjän Lähialuematkojen sivustolla ei mainita sianlihatuotteiden tuontikieltoa, vaikka Venäjällä tiedetään jatkuvasti esiintyvän afrikkalaista sikaruttoa. Matkanjärjestäjät eivät siis näyttäisi mieltävän tautien leviämisen estämistä osaksi kestävää matkailuliiketoimintaa samalla tavoin kuin ilmastokompensaatioita, hotellien ympäristösertifikaatteja, kohdemaan lasten oikeuksien huomioon ottamista, jätteiden kierrätystä, lähimatkailun suosimista, eläinpuistotoiminnan boikotoimista, kohdemaan kulttuurin kunnioitusta ja digitaalisten palveluiden kehittämistä. Ainoastaan Kaleva Travel kehottaa asiakkaitaan olemaan tarkkana eläinaiheisten matkailuaktiviteettien osalta osana kestävää matkailua, ja yhdenneksitoista matkanjärjestäjäksi etukäteistiedon perusteella tarkasteluun mukaan valittu Sagamatkat ohjaa matkailijaa tutustumaan kohdemaansa Islannin tarttuvien tautien ehkäisyohjeisiin.

Tiedotuksen vähäisyys ei tautien nimiä hakusanoina käyttämällä näytä koskevan ainoastaan afrikkalaista sikaruttoa ja maasta toiseen siirrettäviä elintarvikkeita vaan muitakin ihmisten sekä ihmisten ja eläinten välillä leviäviä tauteja, kuten raivotautia ja ekinokokkiloisen aiheuttamaa tartuntaa. Laissa säädetty ja asetuksella tarkennettu tiedonjakovelvollisuus koskee ainoastaan afrikkalaista sikaruttoa, mutta erityisen tärkeää tiedonjakovelvollisuus olisi luontoja eläinaiheisilla teemamatkoilla, kuten ratsastus- ja kalastusmatkoilla, joilla ollaan tekemisissä elävien eläinten tai eläinperäisten elintarvikkeiden kanssa. Tarkasteluun osuneet matkanjärjestäjät järjestävät vain ratsastus- ja kalastusmatkoja eivätkä kaikki näitäkään. Tämä ei kuitenkaan poista sitä riskiä, että matkailijat kohtaavat matkallaan eläimestä tai eläinperäisestä tuotteesta ihmiseen siirtyvän taudinaiheuttajan. Vastuullinen matkanjärjestäjä tiedottaa näistäkin esimerkiksi muistuttamalla rokotusten tarpeellisuudesta.

Selkeimmin eläinaiheiset aktiviteetit otetaan huomioon Islantiin matkoja järjestävän Sagamatkojen internetsivuilla, joilla matkanvaraaja ohjataan suoraan linkistä (www.cvo.is tai www. mast.is) lukemaan islantilaisia viranomaismääräyksiä, jotka koskevat eläinten, eläinperäisten elintarvikkeiden, eläinten rehujen, maatalouskoneiden sekä ratsastus- ja kalastusvarusteiden maahantuontia. Matkailijoille tehdään selväksi, että islantilaisia hevosia ei rokoteta, joten ne 
ovat herkkiä matkailijoiden mahdollisesti mukanaan tuomille infektiotaudeille. Tämän vuoksi ohjeistetaan, että ratsastuksessa käytettävät varusteet pestään vähintään 40-asteisessa vedessä tai kuivapesuna ja desinfioidaan Virkon S -liuoksella; lisäksi varusteiden puhdistuksesta on hyvä esittää todistus Islantiin saapumisen yhteydessä. Varusteet pitää puhdistaa vähintään viisi päivää ennen maahan saapumista. Käytettyjä nahkatavaroita, kuten satuloita, suitsia tai nahkakäsineitä, ei saa tuoda maahan lainkaan. Kalastusvälineitä koskevat samat desinfiointivaatimukset kuin ratsastusvarusteita. Ratsastusvarusteista poiketen kalastusvälineet pitää kuitenkin antaa viranomaisen desinfioitavaksi, ja tästä tulee esittää viranomaisen antama todistus Islantiin saapumisen yhteydessä. Näin pyritään varmistamaan myös vesieläinten terveys maassa, jossa ei esiinny esimerkiksi lohenpoikaisille kohtalokasta lohiloistautia.

Sagamatkojen Islannin ratsastus- ja kalastusmatkojen ohjeistuksessa korostetaan ensisijaisesti vastuullista matkailua ja sen edistämistä Islannin herkän luonnon suojelemiseksi. Tässäkään matkanjärjestäjän vastuu ei viittaa suoraan taudeilta suojaamiseen vaan yleiseen vastuuseen luonnon monimuotoisuuden ja ainutlaatuisuuden säilymisestä. Taudeilta suojautumisen varotoimia olisivat ne varotoimet, joita muutkin kuin matkanjärjestäjät noudattavat yleisesti Suomen pohjoisilla kalajoilla, kuten Teno- ja Näätämöjokien vesistöalueilla, kun näille alueille muilta vesistöalueilta tuotavat veneet, kanootit ja kalastusvälineet pitää ennen käyttöä ensin kuivata ja täydellisen kuivumisen jälkeen desinfioida (Maa- ja metsätalousministeriön asetus 1376/2004).

Suomalainen eläintautilaki on muuttumassa. Uusi lakiehdotus oli lausuntokierroksella keväällä 2020. Tulevassa laissa säädettäisiin uuden Euroopan parlamentin ja neuvoston asetuksen, eläinterveyssäännöstön, täytäntöönpanosta ja täydentämisestä siten, että siinä kuitenkin jätettäisiin jäsenvaltioille kansallista liikkumavaraa (Maa- ja metsätalousministeriö, 2018). Eläintautilaki velvoittaa jo nyt jokaisen, joka osallistuu eläimen tutkimiseen, hoitoon, käsittelyyn, kuljetukseen, lopetukseen, teurastukseen, metsästykseen, pyyntiin, perkuuseen tai tarkkailuun, ilmoittamaan eläintautiepäilystään eläinlääkintäviranomaiselle (Eläintautilaki 441/2013, 14 §). Uuden lain myötä 59a \$:n sisältämästä tiedonantovelvollisuudesta saatetaan säätää uudella asetuksella, mikä tarkoittaa, että nykyiseen suositustyyppiseen käytäntöön saattaa tulla uusia, matkanjärjestäjiä laajemmin ja voimakkaammin sitovia velvollisuuksia. Sen vuoksi olisi tärkeää tietää, kuinka hyvin matkanjärjestäjät nykyisin tuntevat eläintautilakia ja kuinka paljon he seuraavat alaansa vaikuttavia lainmuutoksia. Myös matkanjärjestäjät tulisi ottaa huomioon tärkeänä sidosryhmänä lakeja säädettäessä, jotta heidän velvollisuutensa eivät tulevaisuudessa muuttuisi kohtuuttomiksi rasituksiksi ja viranomaisbyrokratiaksi.

\section{Lähteet}

Aluehallintovirasto (2016). Häntä heiluen tarkastuksesta läpi - muutama koira eristykseen lemmikkiratsiasta. https:/www.avi.fi/web/avi/tiedotteet/tiedotteet-2016/-/asset_publisher/ jW2MZm8XaHOH/content/hanta-heiluen-tarkastuksesta-lapi-muutama-koira-eristykseen-lemmikkiratsiasta-lansi-ja-sisa-suomi-lounais-suomi-

Eläintautilaki 441/2013. 
Laki eläintautilain muuttamisesta 349/2019.

Maa- ja metsätalousministeriön asetus 1376/2004 Tenojoen, Näätämöjoen, Paatsjoen, Tuulomajoen ja Utuanjoen vesistöalueiden suojaamisesta Gyrodactylus salaris -loisen leviämiseltä.

Maa- ja metsätalousministeriö (2018). Eläintautilain uudistaminen Euroopan unionin eläinterveyssäännöstön täytäntöönpanemiseksi. https://mmm.fi/hanke2?tunnus=MMMo37:00/2018

Pekkanen, K. \& Laine, T. (2011/2017). Afrikkalaisen sikaruton mahdollisia maahantuloreittejä riskiprofiilin päivitys 2017. (Eviran tutkimuksia 4/2011, päivitetty 2017).

Ribadeau-Dumas, F., Cliquet, F., Gautret, P., Robardet, E., Le Pen, C. \& Bourhy, H. (2016). Travel-associated rabies in pets and residual rabies risk, Western Europe. Emerging Infectious Diseases, 22, 1268-1271. https://www.ncbi.nlm.nih.gov/pmc/articles/PMC4918150/

Ruokavirasto (2019). Eläintaudit Suomessa 2018. (Ruokaviraston julkaisuja 4/2019.)

Valtioneuvoston asetus 1339/2019 vakavaa eläintautivaaraa koskevasta tiedottamisesta Euroopan unionin sisäisessä matkustajaliikenteessä. 